\title{
Measuring retailer performance: Towards an understanding of productivity
}

\author{
RECEIVED: 27 JUNE, 2000 \\ Hean Tat Keh \\ Department of Marketing, The NUS Business School, National University of Singapore, \\ FBAI, SMI 02-2I, Singapore II759I \\ Tel: (65) 874-3 I52; Fax: (65) 779-594I; e-mail: fbakehht@nus.edu.sg
}

\begin{abstract}
This paper argues that there is not a satisfactory measure of retailer performance. Too many measures are based on accounting and financial measures. These measures do not, however, account for the underlying forces that affect bottom-line performance. To fully understand retailer performance, its productivity must be measured. Here, the concept of productivity is reviewed with regards to retail firms, specifically focusing on input and output constructs, as well as parametric and non-parametric measures of productivity. A research agenda and managerial implications are also presented.
\end{abstract}

\section{INTRODUCTION}

In mid-1999, it was reported in the business press that J. Sainsbury, a major British grocery retailer, planned to reduce 1,100 jobs as a result of poor performance. The company suffered a 3 per cent loss in profits despite a 5 per cent increase in revenue. This was not an isolated incident. In the USA, the grocery retailing industry has long been characterised by very low profit margins. For example, the net profit margin was 0.49 per cent of sales in 1993, and increased to only 1.2 per cent in 1996. ${ }^{1}$ Similarly, in Japan, several grocery chains have also suffered in their performance. Daiei Inc., their largest chain, reported a net loss of $41.3 \mathrm{bn}$ yen, while other chains such as Seiyu and Jusco also experienced declining performance. ${ }^{2}$

Given that grocery retailing is a highly competitive industry, it is imperative that managers try to understand what has gone wrong and how to go about ameliorating the situation. ${ }^{3}$ From financial statements, it is simple to understand a company's bottom-line performance. As emphasised by Eccles, ${ }^{4}$ it is important to consider outcomes beyond financial figures. It is, however, a more difficult task to appreciate what led to the performance achieved, either good or bad. This is why an understanding of productivity is essential. ${ }^{5}$

What is productivity and why do we care about it? Simply, productivity can be defined as a ratio of output to input. More specifically, productivity growth refers to the ability to increase output with given input, or to maintain output with a lower level of input. If two firms use the same amount of input but produce different levels of output, the firm with the higher output is said to

\author{
Dr Hean Tat \\ Keh is an \\ Assistant Professor \\ in the Department \\ of Marketing, \\ National \\ University of \\ Singapore. His \\ research interests \\ include retailing, \\ entrepreneurial \\ marketing and \\ services marketing. \\ He has published \\ widely, including \\ publications in \\ Long Range \\ Planning, Journal of \\ Business and \\ Industrial Marketing \\ and International \\ Review of Retail, \\ Distribution and \\ Consumer Research. \\ He obtained his \\ PhD from the \\ University of \\ Washington.
}


be more productive.

Lovelock noted that marketers are interested in productivity for several reasons:

- it helps to lower costs, thus enabling companies with the lowest cost structure to be the low-price leader

- firms with lower costs than their competitors also generate higher margins

- firms can ensure their long-term future by investing in new technologies and research as a result of higher productivity. ${ }^{6}$

The purpose of this paper is to focus attention on this crucial issue. Although many academicians have studied productivity, usually in a highly abstract and theoretical manner, what it actually means to marketing practitioners, particularly in terms of how they can measure productivity and improve on it, is much more slippery. In this paper the issues involved in understanding the concept of productivity and its measurement are highlighted. A research agenda and managerial implications are also provided.

\section{THE CONCEPT OF PRODUCTIVITY}

There is a vast literature on productivity in retailing. ${ }^{7}$ As such, no attempt to provide an exhaustive literature review will be made here. Rather, the focus will be on two key issues: understanding retailer input and output, and comparing the various measures of productivity. The first issue will be covered in this section, while the latter will be dealt with in the following section.

As defined earlier, productivity is simply a ratio of output over input. As Beckman and Buzzell astutely observed over 40 years ago, 'the technical problems of productivity measurement centre around the definition of stable, meaningful units of output and input'. ${ }^{8}$ Inputs are the factors that a firm uses to produce its goods and services (ie outputs). It is interesting to note that researchers in the late 1950s and early 1960s tended to define input as 'man-hour unit of labour', or some similar variant. ${ }^{9-11}$ It was not until approximately 20 years later that researchers broadened inputs to include other 'internal' factors such as capital, energy, and materials. ${ }^{12}$ While input measurement has its difficulties, the more troublesome concept is that of output measurement. To quote Cox:

'The difficulties of measuring input in marketing as in other areas of economic life are by no means negligible; but they are for the most part problems of technique rather than of concept. It is quite apparent that the most difficult problem to be solved is the devising of meaningful and measurable concepts of output or product. ${ }^{13}$

In the past, many measures of output have been used. In his review, Keh 
observed that these included physical units, sales revenue, value added and gross margin. ${ }^{14}$ Physical units are easy to measure, especially for a manufacturing concern. For a retailer, however, a product can be represented as a bundle of attributes, each of which separately provides utility to the consumer. ${ }^{15}$ As such, this form of output measurement is inadequate. As a result, sales or dollar revenue has often been used as an alternate measure. Sales revenue is a proxy of the monetary value of output. ${ }^{16}$ Despite its popularity, Hall argued that,

'[Sales] is conceptually inept because the output of a shop is the aggregate of services provided by that shop and not the merchandise it sells. Productivity comparisons made by using the volume of sales to measure output are quixotic in the extreme unless the comparisons are made between very similar stores. But where do we find homogenous aggregates of this kind?'17

Another popular measure of retail output is value added. For the retailer, value added equals gross margin minus payments for rent, utilities, and so forth. ${ }^{18}$ This approach corrects for the value of services performed at prior levels of the distribution channel. ${ }^{19}$ This measure of output has, however, been criticised by Hall, Knapp and Winsten, who, in their landmark work, wrote:
'There are probably as many different valuations as there are people. But the idea is not to take any particular one of these, but instead to claim that there is such a thing as a community's valuation, as reflected in the money paid by the community for the services provided ...the community's valuation as measured by value-added is partly a reflection of valuations on the supply-side also. If for example a particular trade attracted only people of inferior competence, this would tend to lower performance and so might even increase value-added. This is hardly what we expect of a measure of output. ${ }^{20}$

Gross margin represents the difference between cost of goods sold and the firm's sales. Ingene claimed that gross margin is the best measure of retail output as it adjusts sales for the cost of merchandise and nothing else. ${ }^{21}$ The main problem with gross margin is, however, that it is a sales dependent measure. Therefore, the disadvantages of using sales as retail output still hold under gross margin. Achabal et al. contended that the gross margin output often results in misleading estimates of the production function, which in turn affects the assessment of the productivity of resources. ${ }^{22}$

Although the aforementioned measures of output have their proponents and detractors, there is wide agreement among marketing academicians that the output of the 
retail firm consists of tangible goods and various distribution services. ${ }^{23-29}$ What are these distribution services? In his landmark work, Bucklin categorised three major types of services: logistical, informational and product functional. ${ }^{30}$ In their subsequent refinement, Betancourt and Gautschi broke down distribution services into: (1) accessibility, (2) product assortment, (3) assurance of product delivery at the desired time and in the desired form, (4) availability of information, and (5) ambience. ${ }^{31,32}$ The distribution services argument explains the simultaneous or concurrent viability of various forms of retailing in the marketing channel, such as convenience stores versus supermarkets. Working independently, Oi provided a similar conceptualisation, ${ }^{33}$ which can be easily reconciled with those of Betancourt and Gautschi.

There has, however, been little empirical analysis that tested the distribution services theory. A major difficulty that prevents its wider usage is the lack of data on them. As expressed by Ratchford and Brown:

'While one might determine how various stores in a given trading area differ on the above attributes [distribution services] through the use of data on consumer perceptions, quantifying how these have changed over time for the entire United States appears to be impossible. The required data simply do not exist.' ${ }^{34}$
More recent work shows, however, that it is not impossible to measure distribution services. ${ }^{35}$ In their analysis of retail margins, Betancourt and Gautschi used US census data to proxy the five distribution services. ${ }^{36}$ The concern remains that Betancourt and Gautschi analysed macro (aggregate) level data, which have limited utility for the store manager who is concerned about the store's productivity level. To this end, some effort is already underway to measure distribution services at the micro (or firm) level. ${ }^{37,38}$

\section{THE MEASUREMENT OF PRODUCTIVITY}

Although several measures of productivity have been used, they can generally be categorised into parametric or non-parametric approaches. Parametric measures are so named because they typically involve the construction of a production or cost function that can be tested statistically. By implication, nonparametric measures do not have parameters that can be tested statistically.

\section{Parametric estimation}

Parametric estimations occur when a production or cost function is constructed. These functions cannot be observed directly from the data. The parameters of a cost or production function must be estimated statistically. There are two general parametric approaches: ${ }^{39}$ 
- estimation of a production function, productivity is defined as the shift (upward) of the production function

- estimation of a cost function, productivity is defined as the shift (downward) over time of the cost function.

Essentially the cost and production functions form two sides of the same coin. Estimating production functions, however, becomes cumbersome when the firm produces multiple outputs. Statistically, correlation between the regressors and the error creates simultaneity. By assuming cost-minimising behaviour by the firm, the relevant properties of production functions are embodied in the firm's cost functions, which are easier to estimate. ${ }^{40}$ For the purpose of discussion here, the cost function is subsumed under the production function.

Total factor productivity (TFP) is an estimate formulated on the implicit assumption that a production function accurately describes the maximum output attainable from a set of factor inputs. Bloom reasoned that 'only by relating output to all associated inputs can it be determined whether or not there has been a net savings of inputs per unit of output'. ${ }^{41}$

Perhaps the most common representation of TFP is the Cobb-Douglas production function. The attraction of the Cobb-Douglas production function lies in its simplicity and robustness, which has encouraged several marketing researchers to use it in measuring productivity in retailing. For example, Ofer used value added as output and labour and capital as inputs to estimate scale effects in retail trade from a cross section of retail stores in Israel. $^{42}$ Following this tradition, Ingene and Lusch estimated the production function for US department stores for the year 1972. ${ }^{43}$ Data restrictions prevented them from using value added as the output measure, instead they assumed that cost of goods sold is a constant percentage of sales, and used sales as the output measure. For labour input, they used average number of man-hours. For capital input, they used total floor space as the surrogate measure.

Doutt also used TFP to measure productivity in fast-food retailing. ${ }^{44}$ The output measure was total value added, while the inputs consisted of labour (man-hours worked per week), capital (insured or replacement value of facilities and equipment) and service (capital investment reflected by the extent of customer capacity). Only labour and capital inputs were found to be significant.

In their industry-wide study of productivity in food retailing between 1959 and 1979, Ratchford and Brown used real value added as the single output. ${ }^{45}$ The input measures consisted of labour, capital, and intermediate goods. Among other results, they found that TFP in the food industry grew at a much slower rate than in manufacturing.

Despite the appeal of TFP measurement, it is not universally popular. 
Several researchers in marketing have rejected it in favour of partial factor productivity (PFP). In preferring PFP to TFP, Lusch and Moon argued that:

'TFP is defined as the measure of efficiency of all employed inputs. Its measurement is relatively primitive, and therefore its use may be misleading. The main cause of confusion lies in the fact that TFP requires the development of an input index, for which some type of weighting system is needed. But such systems are usually based on subjective criteria. Besides the problem of index construction, TFP provides less meaningful information to managers for use in decision making., ${ }^{46}$

Among the various examples of PFP measurement available, the most popular is labour productivity. ${ }^{47-49}$ In advocating its use, Lusch and Moon noted the following advantages:

- when labour and capital are compared, the time commitment is shorter for labour. Since labour is more controllable and flexible than other inputs, managers must manage their labour better

- the relatively low growth in retail labour productivity. Retailers are confronted by a major imperative to increase labour productivity

- the close relationship between labour productivity and profitability. ${ }^{50}$

In an early analysis of labour productivity in retailing, Waldorf looked at the food wholesaling and retailing industry between the years 1929 and $1958 . .^{51}$ The measures of output he used were an index of gross output and two indices of net output, a double-deflated value added series and a margin-weighted series. Waldorf's major findings were:

- net output per man-hour grew at an average annual rate of 2.8 per cent

- the double-deflated value added measure of net output rose significantly more than the marginweighted measure during the period

- gross output grew at about the same average annual rate as net output measured by double-deflated value added.

In contrast, Ingene proposed that the best output measure of labour productivity in retailing was dollar sales, and for the input measure he used number of employees, resulting in sales per employee as the productivity measure. ${ }^{52}$ Among his more interesting findings were that:

- an increase in capital intensity increases labour productivity

- as average store size increases, labour productivity decreases

- as retail space saturation increases, labour productivity decreases

- as mobility increases due to greater availability of cars, labour productivity will increase.

In their look at labour productivity in the retail hardware industry, Lusch and Moon found that labour productivity is 
non-linear in the store size parameter; increasing up to a point, after which it declines. ${ }^{53}$ This is supported by Good, who discovered that the optimum grocery store size is 22,023 square feet, below or above which productivity (measured as value added per manhour) decreases. ${ }^{54}$

Most parametric studies of productivity used either TFP or PFP measures. It is difficult to judge the superiority of either measure as there are critics and supporters for both camps. In an attempt to reconcile the differences between the two measures, Keh analysed the productivity of a chain of US grocery stores over 10 years, and found that the results from TFP and labour productivity were essentially similar. In addition, by estimating the translog cost function, he found empirical support for the theoretical arguments that distribution services are a source of increasing returns to scale in retailing. ${ }^{55}$

\section{Non-parametric measures}

As an applied discipline, marketing has relied on many tools developed in other disciplines, especially economics and management science. In economics, several nonparametric measures of productivity have been developed, mainly based on index numbers. ${ }^{56}$ Index number techniques are non-parametric as they can be directly constructed from data without the need for statistical estimation of a production or cost function. These measures have typically been used to measure productivity at the macroeconomy level. As such, they have not been actively applied in marketing.

More recently, however, a nonparametric technique known as Data Envelopment Analysis (DEA) has experienced greater application in marketing. Charnes, Cooper and Rhodes first introduced DEA as an evaluation tool for decision-making units. ${ }^{57}$ Since then, there have been several hundred applications of DEA. ${ }^{58}$ As opposed to parametric approaches, DEA does not require any assumption about the functional form. It calculates a maximal performance measure for each decision-making unit (DMU) relative to all other DMUs in the population (all DMUs lie on or below the efficient frontier).

Instead of following the approach in statistical regressions, which use a single optimisation to come as close as possible to all points, DEA makes $n$ optimisations, and comes as close as possible to each of $n$ observations. DEA is a 'data oriented approach' for evaluating the performance of DMUs which are regarded as responsible for converting inputs into outputs.

DEA measures the relative technical efficiency (RTE) of the transformation of inputs into outputs by similar (ie comparable) DMUs. Mathematically, for $n$ DMUs using $m$ inputs to produce $s$ outputs, DEA maximises for each DMU,

$$
\mathrm{RTE}_{k}=\sum_{i=1}^{s} a_{i} Y_{i, k} / \sum_{j=1}^{m} b_{j} X_{j, k}
$$

subject to the constraints that (a) none of the ratios exceeds 1 for any DMU 
and (b) the weights $a_{i}$ and $b_{j}$ are non-negative, where $Y$ and $X$ are the output and input factors, respectively. DMUs with RTE equal to one define the 'best practice' frontier since they (individually or in combination) serve as references in rating the other DMUs.

Although developed by management scientists, DEA has seen several applications in marketing and retailing. In an application of DEA in fast-food retailing, Banker and Morey (1986) introduced exogenous (non-controllable) inputs. ${ }^{59}$ The outputs were breakfast, lunch and dinner sales. The controllable inputs were supplies and labour, the allocative inputs were store age and advertising, and the environmental factors were demographic and availability of a drive-in window. They found that reflecting the fixed nature of some inputs enabled the identification of savings in controllable inputs, or increases in the controllable outputs. In a more recent refinement, which also looked at a chain of fast-food restaurants, Donthu and Yoo used four input factors (store size, store manager experience, store location and promotion expenses) and two output variables (sales and customer satisfaction). In addition to tracking store performance over time, they also performed sensitivity analysis of individual stores using DEA. ${ }^{60}$ Similar work has also been conducted by Athanassopoulos on 31 restaurants in the UK. ${ }^{61}$ Using both constant and variable returns to scale, he analysed aggregate market and site efficiencies, respectively. Three variants of efficiency were proposed to meet the needs of different tiers of management.

In a similar vein, Sherman and Ladino compared the relative efficiency of 33 branches of a large bank. ${ }^{62}$ The inputs were labour (customer service [tellers], sales service [platform], and manager), expenses (excluding personnel and rent) and office size. The five output measures of the services were

- deposits, withdrawals and cheques cashed

- bank cheques, travellers' cheques, bonds sold and redeemed, and coupons

- night deposits

- loans (both mortgage and consumer)

- new accounts (time, savings or certificates of deposit).

By using the most efficient branches as benchmarks, the bank was able to save about US\$6m in expenses.

Thomas et al. used DEA to study the efficiency of a specialty retailer with over 500 stores. $^{63}$ The output measures were sales revenue and contribution dollars. The four input factors were labour, experience, location-related costs and internal processes. This paper pioneered the use of DEA with assurance regions. This means that business objectives were incorporated in the assignment of weights, something that has value to management.

For the grocery industry, Athanassopoulos and Ballantine studied 21 
grocers in the UK. ${ }^{64}$ Their input factors consisted of capital employed, fixed assets, number of employees, number of outlets and sales area. The sole output variable was sales revenue. Certain chains such as Tesco and Marks and Spencer were inefficient with regards to sales potential. In a more recent study, Keh and Chu compared the productivity of a chain of US grocery stores using two different methodologies, multilateral comparisons of productivity and DEA. ${ }^{65}$ Their effort represents the first test of distribution services as the output variables of the retail firm, in accordance with theory. The results from both methodologies were quite similar, providing further support for DEA.

Although the strengths of DEA are well documented, ${ }^{66}$ it also has certain disadvantages: ${ }^{67,68}$

- it is a non-parametric measure so no statistical tests can be performed. A DMU can enjoy the benefits of unique circumstances, thus distorting the shape of the frontier. The researcher has to decide whether or not to include this outlier

- the sample data are enveloped by a deterministic frontier. Any deviation from this frontier is attributed solely to inefficiency, thus discounting the effects of noise, random shocks, measurement and omitted variables

- the outcomes are dependent on the factors entered into the analysis and the numerical values accorded to qualitative factors. Therefore, attention should be focused on the differences between efficiency scores rather than their absolute values ${ }^{69}$

- DEA is particularly sensitive to measurement error since there is no process currently available within DEA to identify or deal with measurement error

- stable DEA results also require a large number of observations, particularly when the number of inputs and outputs are increased. As such, it may not be suitable for measuring the efficiency of small chains.

\section{DISCUSSION AND FUTURE RESEARCH}

This paper has dealt with two major issues in measuring the productivity performance of retail firms: the constructs of input and output factors, as well as productivity measurement. Given the wide disparity of research findings and methodologies, as discussed in the previous sections, it is worthwhile discussing their implications for managers and also in setting a research agenda.

From an academic viewpoint, much progress has been made in productivity research. For example, refinements in productivity concepts have been made, particularly with regards to retail output. It is now clear that the retail firm actually produces a set of market goods that are bundled with implicit distribution services. While this is widely acknowledged, there have been 
relatively few works to date that have tested distribution services theory. More effort should be generated in this direction. In particular, academic researchers should attempt to make their research relevant to the needs of managers.

There is less consensus on the 'ideal' measure of productivity. In an interesting comparison of parametric and non-parametric measures, Bauer et al. noted some similarities and differences between them. ${ }^{70}$ Generally, parametric methods are consistent with one another, and likewise with non-parametric methods, but the two sets of methods are not generally mutually consistent. DEA yielded lower average efficiencies, and identified the best and worst DMUs differently from parametric methods. They also found that parametric measures were generally highly positively correlated with the standard nonfrontier performance measures, whereas DEA enjoyed much lower correlation. Despite their findings, Bauer et al. cautioned against overgeneralisation, as it is not clear if their results were robust. Perhaps it is beneficial to reflect on the sage advice of Cox, whose words still ring true after 50 years:

'There can be no one best method of measuring productivity. The best measure will vary with the definition and the purpose. For this reason a meaningful discussion of productivity in distribution and its measurement must start with a clear understanding that the questions generally asked about the productivity about distribution differ from those most commonly asked about productivity in general. ${ }^{, 71}$

Future research can also compare the productivity performance of retailers across various industries (groceries, gasoline, department stores, fast-food restaurants, banks, etc.). The analysis can be either cross-sectional or time-series in nature, or both (using panel data). Most of the extant studies in the literature study productivity using cross-sectional data, but a longitudinal analysis will yield more information on the performance of a firm over time. This will also enhance knowledge on the evolution of retailing.

While academicians are constantly tackling new retailing problems, it is necessary also to reflect on how retail productivity is of importance and relevance to managers. Since investors and other stakeholders emphasise financial performance, managers are constantly under pressure to show positive financial results. As argued previously, the answer may well lie in improved productivity. In particular, the productivity assessment of multiple outlets is a significant issue. It is, however, surprising to note relatively few studies that have addressed this topic. $^{72}$ Many managers, even those possessing MBAs, are not familiar with advanced statistical methods. As such it is hoped that the discussion heretofore is a useful summary for managers. They 
need to be aware of the developments in academic research that are useful in their work. In this regard, previous and future research in productivity should be of great interest to them.

\section{REFERENCES}

1 Coleman, C. Y. (1997) 'Finally, supermarkets find ways to increase their profit margins', Wall Street Journal, May 29, pp. A1, A6.

2 Kachi, H. (1999) 'Japan's supermarkets report lower sales', Asian Wall Street Journal, April 22, p. 6.

3 Keh, H. T. and Park, S. Y. (1997) 'To market, to market: The changing face of grocery retailing', Long Range Planning, Vol. 30, No. 6, pp. 836-846.

4 Eccles, R. G. (1991) 'The performance measurement manifesto', Harvard Business Review, Vol. 69, January-February, pp. 131-137.

5 Achabal, D. D., Heineke, J. M. and McIntyre, S. H. (1984) 'Issues and perspectives on retail productivity', Journal of Retailing, Vol. 60, Fall, pp. 107-127.

6 Lovelock, C. H. (1996) 'Services marketing', 3rd ed., Prentice Hall, Upper Saddle River, NJ.

7 For a review see Parsons, L. J. (1994) 'Productivity versus relative efficiency in marketing: Past and future?' in Laurent, G., Lilien, G. L. and Pras, B. (eds) 'Research traditions in marketing', Kluwer, Boston, pp. 169-196.

8 Beckman, T. N. and Buzzell, R. D. (1958) 'Productivity: Facts and fiction', Business Horizon, Vol. 1, Winter, pp. 24-38.

9 ibid.
10 Beckman, T. N. (1960) 'Measuring productivity in marketing', Proceedings of the Business and Economic Statistics Section, American Statistical Association, Washington, DC, pp. 308318.

11 Cox, R. (1960) 'Productivity in marketing - prospects for improvements in the sixties', Proceedings of the Business and Economic Statistics Section, American Statistical Association, Washington, DC, pp. 319-322.

12 eg Bucklin, L. P. (1978a) 'Research in productivity measurement for marketing decisions', in Sheth, J. N. (ed.) Research in Marketing, Vol. 1, JAI Press, Greenwich, CT, pp. 1-22.

13 Cox, R. (1948) 'The meaning and measurement of productivity in distribution', Journal of Marketing, Vol. 12, April, p. 438.

14 Keh, H. T. (1997) 'The classification of distribution channel output: A review', International Review of Retail, Distribution and Consumer Research, Vol. 7, April, pp. 145-156.

15 Bucklin, L. P. (1978b) 'Productivity in marketing', American Marketing Association, Chicago.

16 Parsons (1994) op. cit.

17 Hall, M. (1974) 'Investment and productivity', in Thorpe, D. (ed.) 'Research into retailing and distribution', Saxon House, Westmead, pp. 13-22.

18 Ingene, C. A. (1984) 'Productivity and functional shifting in spatial retailing: Private and social perspectives', Journal of Retailing, Vol. 60, Fall, pp. 15-36.

19 Beckman, T. N. (1957) 'The value added concept as a measure of output', 
Advanced Management, Vol. 22, April, pp. 6-9.

20 Hall, M., Knapp, J. and Winsten, C. (1961) 'Distribution in Great Britain and North America: A study in structure and productivity', Oxford University Press, London.

21 Ingene (1984) op. cit.

22 Achabal et al. (1984) op. cit.

23 Dean, J. (1960) 'Marketing productivity and profitability', Productivity Measurement Review, Vol. 20, February, pp. 47-55.

24 Bucklin (1978a) op. cit.

25 Bucklin (1978b) op. cit.

26 Arndt, J. and Helgesen, T. (1981) 'Marketing and productivity: Conceptual and measurement issues', in Bernhardt, K. et al. (eds) 'AMA Educators' Conference Proceedings', American Marketing Association, Chicago, pp. 81-84.

27 Achabal et al. (1984) op. cit.

28 Good, W. S. (1984) 'Productivity in the retail grocery trade', Journal of Retailing, Vol. 60, Fall, pp. 81-97.

29 Keh (1997) op. cit.

30 Bucklin (1978b) op. cit.

31 Betancourt, R. R. and Gautschi, D. A. (1988) 'The economics of retail firms', Managerial and Decision Economics, Vol. 9, pp. 133-144.

32 Betancourt, R. R. and Gautschi, D. A. (1990) 'Demand complementarities, household production, and retail assortments', Marketing Science, Vol. 9, Spring, pp. 146-161.

33 Oi, W. Y. (1992) 'Productivity in the distributive trades: The shopper and the economies of massed reserves', in Griliches, Z. (ed.) 'Output measure- ment in the service sectors', University of Chicago Press, Chicago, pp. 161191.

34 Ratchford, B. T. and Brown, J. R. (1985) 'A study of productivity changes in food retailing', Marketing Science, Vol. 4, Fall, pp. 292-311.

35 Betancourt, R. R. and Gautschi, D. A. (1993) 'The outputs of retail activities: Concepts, measurement and evidence from US census data', Review of Economics and Statistics, Vol. 75, May, pp. 294-301.

36 ibid.

37 Keh, H. T. (1999) 'Productivity and scale economies in retailing: A test of distribution services theory', Working Paper, National University of Singapore.

38 Keh, H. T. and Chu, S. (1999) 'Measuring retail productivity: A comparison of parametric and non-parametric approaches', Working Paper, National University of Singapore.

39 Oum, T. H., Tretheway, M. W. and Waters, W. G. (1992) 'Concepts, methods and purposes of productivity measurement in transportation', Transportation Research A, Vol. 26A, November, pp. 493-505.

40 ibid.

41 Bloom, G. F. (1972) 'Productivity in the food industry: Problems and potential', Cambridge, MA, MIT Press.

42 Ofer, G. (1973) 'Returns to scale in retail trade', Review of Income and Wealth, Vol. 19, December, pp. 363384.

43 Ingene, C. A. and Lusch, R. F. (1979) 'Estimation of a department store 
production function', International Journal of Physical Distribution and Materials Management, Vol. 9, No. 6, pp. 272284.

44 Doutt, J. T. (1984) 'Comparative productivity performance in fast-food retail distribution', Journal of Retailing, Vol. 60, Fall, pp. 98-106.

45 Ratchford and Brown (1985) op. cit.

46 Lusch, R. F. and Moon, S. Y. (1984) 'An exploratory analysis of the correlates of labour productivity in retailing', Journal of Retailing, Vol. 60, Fall, p. 39.

47 Waldorf, W. H. (1966) 'Labour productivity in food wholesaling and retailing, 1929-1958', Review of Economics and Statistics, Vol. 48, February, pp. 88-93.

48 Ingene, C. A. (1982) 'Labor productivity in retailing', Journal of Marketing, Vol. 46, Fall, pp. 75-90.

49 Lusch and Moon (1984) op. cit.

50 ibid.

51 Waldorf (1966) op. cit.

52 Ingene (1982) op. cit.

53 Lusch and Moon (1984) op. cit.

54 Good (1984) op. cit.

55 Keh (1999) op. cit.

56 Diewert, W. E. (1989) 'The measurement of productivity', Working Paper, Dept. of Economics, University of British Columbia.

57 Charnes, A., Cooper, W. W. and Rhodes, E. (1978) 'Measuring the efficiency of decision-making units', European Journal of Operational Research, Vol. 2, pp. 429-444.

58 Seiford, L. H. (1996) 'Data envelopment analysis: The evolution of the state of the art (1978-1995)', Journal of Productivity Analysis, Vol. 7, pp. 99-137.
59 Banker, R. D. and Morey, R. D. (1986) 'Efficiency analysis for exogenously fixed inputs and outputs', Operations Research, Vol. 34, July-Aug, pp. 513521.

60 Donthu, N. and Yoo, B. (1998) 'Retail productivity assessment using data envelopment analysis', Journal of Retailing, Vol. 74, No. 1, pp. 89-105.

61 Athanassopoulos, A. D. (1995) 'Performance improvement decision aid systems (PIDAS) in retailing organizations using Data Envelopment Analysis', Journal of Productivity Analysis, Vol. 6, pp. 153-170.

62 Sherman, H. D. and Ladino, G. (1995) 'Measuring bank productivity using data envelopment analysis (DEA)', Interfaces, Vol. 25, March-April, pp. 60-73.

63 Thomas, R. R., Barr, R. S., Cron, W. L. and Slocum, J. W. Jr. (1998) 'A process for evaluating retail store efficiency: A restricted DEA approach', International Journal of Research in Marketing, Vol. 15, No. 5, pp. 487-503.

64 Athanassopoulos, A. D. and Ballantine, J. A. (1995) 'Ratio and frontier analysis for assessing corporate performance: Evidence from the grocery industry in the UK', Journal of the Operational Research Society, Vol. 46, pp. 427-440.

65 Keh and Chu (1999) op. cit.

66 Charnes, A., Cooper, W. W., Lewin, A. Y. and Seiford, L. M. (1994) 'Data Envelopment Analysis: Theory, methodology, and application', Kluwer, Boston.

67 Parsons (1994) op. cit.

68 Thomas et al. (1998) op. cit. 
69 Golany, B. and Roll, Y. (1989) 'An application procedure for DEA', Omega, Vol. 17, No. 3, pp. 237-250.

70 Bauer, P. W., Berger, A. N., Ferrier, G. D. and Humphrey, D. B. (1998) 'Consistency conditions for regulatory analysis of financial institutions: A comparison of frontier efficiency methods',
Journal of Economics and Business, Vol. 50, No. 2, pp. 85-114.

71 Cox (1948) op. cit., p. 433.

72 Kamakura, W. A., Lenartowicz, T. and Ratchford, B. T. (1996) 'Productivity assessment of multiple retail outlets', Journal of Retailing, Vol. 72, No. 4, pp. 333-356. 